\title{
Supporting Information Leadership in a Culture of Change: Researchers in School Librarianship
}

Laurel A. CLYDE

Professor, Library and Information Science Department, The University of Iceland

\begin{abstract}
One aspect of the author's ongoing "Research and Researchers in School Librarianship" project is described here, a study of the researchers in this field. Data collection was based on a questionnaire survey of "current researchers" who have published research articles or papers in the field of school librarianship, in English, from 1999 to 2003 inclusive. Data collection and analysis was ongoing when this conference paper was prepared; this is a preliminary report based primarily on the returns of researchers who had published three or more research articles during the five-year period. Questions addressed include the following: Who writes research articles and papers in English in the field of school librarianshop? How many researchers are there in our field? What are the characteristics of the researchers? What issues are of concern to the researchers and what do they perceive to be the barriers to doing research?
\end{abstract}

\section{Introduction}

The publicity brochure for this conference outlines six strands related to the conference theme of "Information Leadership in a Culture of Change". Each of those strands raises a number of questions. For example, in relation to Information Literacy, the question is, "What are the current models, research, initiatives, and programs relating to information literacy and how do they help in an international arena to further information literacy in schools and other organizations?” In relation to Knowledge Management, the question is, "How can knowledge sharing advance teaching practice within schools and beyond?”. One potential source of answers to these and similar questions is reflective practice based on the collection and analysis of data and information related to day-to-day professional practice within the school. Another potential source is published research in the field of school librarianship. It is this second source of information, research in school librarianship, that is the focus of this paper for the Ninth International Forum on Research in School Librarianship. The work done by researchers creates an important resource for information leadership, particularly in a culture of change.

The paper describes a research study, "Researchers in School Librarianship", that is part of a wider "Research and Researchers in School Librarianship" project. This larger international longitudinal project has been investigating published research in the field of school librarianship from 1991 onwards. A paper for the 2001 IASL conference in New Zealand (Clyde, 2001) discussed the research methodologies to be used in the project as a whole; a paper for the 2002 IASL conference in Malaysia (Clyde, 2002) discussed trends in the research literature in our field, the topics that have been studied over the years since 1991, and the research methodologies that have been used. The present paper for the 2005 IASL conference in Hong Kong discusses the characteristics of the researchers who have published research articles and papers in our field, in English, since 1991. While there has been a considerable amount of research related to the research output in librarianship in 
general (see, for example, Cano \& Rey, 1993; Rochester, 1995; Koufogiannakis \& Slater, 2004) and school librarianship in particular (see, for example, Stroud, 1982; Grover \& Fowler, 1993; Henri \& Freeman, 1998) over the years, it is most uncommon that the researchers are studied (one of the few examples is Blake, 1994). The coverage of this paper both complements the 2001 and 2002 papers and extends the "Research and Researchers in School Librarianship" project in a new but related direction. It also raises questions that need to be addressed if our profession as a whole is to be able to rely on the research as a basis for decision-making.

\section{Aims of the Research}

The aims of the study of current researchers in the field of school librarianship include the following:

- To identify the people who write research articles and papers;

- To describe the characteristics of the people who write research articles and papers;

- To identify any trends related to the researchers, their characteristics, and the factors that influence their work;

- To identify and analyse issues of concern to the researchers and barriers to research in our field;

- To identify any differences between more active and less active researchers.

A full analysis of the research data and discussion of the results is expected to identify and draw attention to any concerns that could affect the future of research work in our profession, and/or that fall within the remit of the International Association of School Librarianship; this paper is the beginning of this process.

\section{Methodology}

The research methodology for the study of researchers is dependent upon a database created for the wider "Research and Researchers in School Librarianship" project. This database includes bibliographic and other information about research articles and papers in the field of school librarianship, published in English from 1991 onwards. The criteria for identifying research articles and papers were established through a research project carried out in Iceland (Pálsdottir et al., 1997); the boundaries of the research field of school librarianship were established through a 1996 IASL publication project (Clyde, 1996). Only publications in English were considered because there are few specialist avenues for publication of the results of school librarianship research in other languages. The work of Finnish researchers Kalervo Järvelin and Pertti Vakkari $(1990 ; 1993)$ informed the early planning. Various strategies have been used to identify relevant articles and papers, including searches of online databases (such as ERIC, LISA, Library Literature and Information Science, and British Education Index), and scanning all issues of more than 70 research journals from 1991 onwards (Clyde, 2001). Whenever a relevant article was found in any issue of a journal, then all issues of the journal from the beginning of 1991 were scanned.

The research database was used to identify potential groups of "current active researchers" in the field of school librarianship internationally. For planning purposes, the data for the five-year period 1996 to 2000 inclusive were used as a basis for 
making decisions about "more active" and "less active" researchers. As Table 1 (based on data for 1996 to 2000 inclusive) shows, the total numbers were not large. The great majority of the researchers (196 or 74.5\%) had published, alone or with others, just one research article or paper in English related to school librarianship through the five-year period. On the basis of the information in Table 1, it was decided to use two survey groups: those active researchers who had published three or more relevant research articles or papers in the five-year period covered by the research, and those who had published one or two relevant articles or papers in the same period. Those who had published three or more research articles and papers through the lustrum were separated from the other less active researchers, so that data from the more active researchers could be compared with the data from those who were less active.

Table 1: Possible Survey Frames Based on Data for 1996-2000 Inclusive

\begin{tabular}{l|l}
\hline Criteria & Researchers (\%) \\
\hline At least three research articles/papers about at least two projects & $36(13.7 \%)$ \\
Two research articles/papers about two projects & $23(8.7 \%)$ \\
Two research articles/papers about one project & $8(3.0 \%)$ \\
One research article/paper about one project & $196(74.5 \%)$ \\
\hline TOTAL & $263(100 \%)$ \\
\hline
\end{tabular}

Table 2:

Research Publications of the More Active Researchers, 1996-2000 Data $(\mathrm{n}=36)$

\begin{tabular}{l|l}
\hline Number of Published Articles/Papers & Number of More Active Researchers (\%) \\
\hline 3 articles/papers & $13(36.1 \%)$ \\
4 articles/papers & $6(16.6 \%)$ \\
5 articles/papers & $5(13.8 \%)$ \\
6 articles/papers & $4(11.1 \%)$ \\
7 articles/papers & $2(5.5 \%)$ \\
8 articles/papers & $3(8.3 \%)$ \\
9 articles/papers & $1(2.8 \%)$ \\
10 articles/papers & $1(2.8 \%)$ \\
11 articles/papers & - \\
12 articles/papers & - \\
13 articles/papers & $1(2.8 \%)$ \\
\hline TOTAL & $36(100 \%)$ \\
\hline
\end{tabular}

Table 3: Distribution of Authorships of Research Articles/Papers in School Librarianship, 1996-2000 Data

\begin{tabular}{l|lllllll}
\hline $\begin{array}{l}\text { Number of Authors Per } \\
\text { Article/Paper }\end{array}$ & 1996 & 1997 & 1998 & 1999 & 2000 & Totals \\
\hline $\begin{array}{l}\text { Articles/papers with one author } \\
\text { Articles/papers with two authors }\end{array}$ & 42 & 43 & 42 & 51 & 38 & 216 \\
$\begin{array}{l}\text { Articles/papers with three } \\
\text { authors }\end{array}$ & 2 & 1 & 4 & 3 & 6 & 16 \\
$\begin{array}{l}\text { Articles/papers with more than } \\
\text { three authors }\end{array}$ & 2 & 1 & - & 2 & 1 & 6 \\
\hline TOTAL ARTICLES/PAPERS & 55 & 66 & 61 & 74 & 58 & 314 \\
\hline
\end{tabular}


However, it has to be recognised that this division into two groups is a convenience division; some of the "more active" researchers were still publishing an average of less than one research article or paper in the field of school librarianship per year. Only 36 authors (two of whom are now deceased) published, alone or with others, three or more research articles and papers in the field of school librarianship through the five-year period 1996 to 2000. Together, they published 182 of the 314 research articles and papers in the field of school librarianship published through those five years (or 57.9\%, see Table 3). Thus in this small group, we are looking at the core contributors to the research literature of school librarianship from 1996 to 2000 inclusive. Of the 36, 13 (or 36.1\%) had published just three articles or papers, alone or with others, through the period. This does not represent a particularly high level of research productivity by today's university standards. Only 17 of these 36 researchers (or $47.2 \%$, representing just $6.5 \%$ of the 263 researchers) averaged at least one published research article or paper in the field of school librarianship per year (that is, five or more published articles/papers through the period). Table 2 shows the research publications of the "most active" group of 36 researchers.

For the 2004/2005 "Researchers in School Librarianship” survey, the cut-off date of December 2003 is being used. A later date could not be used because articles and papers published in 2004 and 2005 were still being identified at the time of writing. The active researchers included in the survey were those who had published at least three research articles or papers, in English, as author or co-author, from 1999 to 2003 inclusive, while the less active researchers included in the survey were those who had published one or two research article/s or paper/s, in English, as author or co-author, from 1999 to 2003 inclusive (see Table 4).

Current contact information for authors was recorded in the database from information provided on the published articles and papers; where contact information was not available, then directories, web search engines and other sources were used to locate this information. However, some authors were contacted through conferences, for example the 2004 conference of the International Association of School Librarianship in Dublin, Ireland, and the 2004 IFLA World Library and Information Congress in Buenos Aires, Argentina.

The data collection instrument was a printed questionnaire, distributed in two versions: one for the most active researchers, and one for all the other researchers. Apart from the title on the form and the wording of the Introduction, the two questionnaires were identical. They contained some questions about the researcher, questions about research in school librarianship, and questions related to current issues identified through a comprehensive literature review. Most questions required the respondent to tick a box or to circle a number on a scale; only a few required the respondent to write words or sentences. A covering letter explained the project. The questionnaire had been trialed with a group of researchers in fields outside of but related to school librarianship (for example, librarianship and education), and modified as indicated by their comments. It was distributed to the researchers in person where possible (usually at conferences); if personal delivery was not possible, then it was mailed or sent by other appropriate strategies (for example, as an email attachment). All possible steps were taken and will be taken to maximise the response 
rate. At the time of preliminary data analysis for this paper, follow-up letters (with a new copy of the questionnaire) had been sent to the current active researchers who had not responded to the first mailing; some responses had been received to this second mailing and were included in the analyses. Similar letters were being prepared to go to the researchers who had written or co-authored one or two research articles or papers in the five-year period to the end of 2003.

The data are being analysed using the SPSS statistical package, and, where necessary, content analysis is being undertaken of any text data.

\section{Results}

Early in 2004, before the questionnaires were distributed, some preliminary analyses were undertaken of entries in the project database, to describe some of the characteristics of the researchers in the field of school librarianship, for a paper written with Dianne Oberg for the 2004 IFLA Conference (see Clyde \& Oberg, 2004). These analyses were limited to a sub-set of the database, the authors of research articles published in the IASL journal School Libraries Worldwide from its establishment in 1996 to 2004. It is worth noting, though, that this journal had come to be the most significant international research journal in the field of school librarianship (measured by the number of research articles published each year) by the end of the twentieth century (Clyde, 2002). As a result of these analyses, we already have some information about the researchers (Clyde \& Oberg, 2004). For example, we know that:

- More of the researchers are working in developed countries than in developing countries

- The majority of the researchers are working in the United States, Australia and Canada

- The majority of the researchers are university or college faculty members

- Even when the research is based in schools, it is more likely to be reported by a university or college faculty member

- Only a small proportion of the researchers have published more than three research articles or papers related to school librarianship in the five-year period; there are very few high-performing researchers.

These points raise a number of concerns, some of which will be taken up by Dianne Oberg as Editor of IASL's research journal School Libraries Worldwide.

The questionnaire was very comprehensive in its coverage of issues related to research in school librarianship; only those results directly related to the aims of this paper will be presented here. In looking at these results, it needs to be borne in mind that both data collection and data analysis were still proceeding in March/April 2005 (at the time of writing) and indeed may not be completed by the time of the 2005 IASL conference in Hong Kong in July. More detailed results will be presented in articles to be published in 2006.

Who writes research articles and papers in English in the field of school librarianship? How many researchers are there in our field? What trends, if any, are apparent?

The total number of people responsible for research articles or papers published in English in the field of school librarianship in the five-year period 1999- 
2003, as author or co-author, was 297, an increase from the 263 in 1996-2000. Almost three-quarters of the authors (74.1\%) produced only one article or paper, as author or co-author, in the five-year period 1999-2003, a proportion virtually unchanged from 1996-2000 (when it was 74.5\%). Only 43 authors (14.8\%) had published three or more articles or papers, alone or with others, through the period 1999-2003. Although this was an increase on the number for 1996 to 2000 inclusive (when 36 authors fell into this group of more active researchers), nevertheless there was no significant increase in the percentage of the researchers in this more active group (14.5\% for 1999-2003 as against $13.7 \%$ for 1996-2000). The number of researchers publishing three or more articles or papers does not represent a particularly high level of research productivity by today's university standards. Only 16 of the 43 researchers in the more active group for $1999-2003$ (or $37.2 \%$, representing just $5.4 \%$ of the 297 researchers) averaged at least one published research article or paper in the field of school librarianship per year (that is, five or more published research articles/papers through the period). Table 4 shows the research publications of the researchers who formed the survey population.

Table 4:

Research Publications of the Researchers, 1999-2003 Inclusive, Published in English

\begin{tabular}{l|l}
\hline Number of Published Articles/Papers & Number Researchers (\%) \\
\hline 1 article/paper & $220(74.1 \%)$ \\
2 articles/papers & $34(11.4 \%)$ \\
3 articles/papers & $20(6.7 \%)$ \\
4 articles/papers & $7(2.4 \%)$ \\
5 articles/papers & $5(1.7 \%)$ \\
6 articles/papers & $4(1.3 \%)$ \\
7 articles/papers & $3(1.0 \%)$ \\
8 articles/papers & $1(0.3 \%)$ \\
9 articles/papers & - \\
10 articles/papers & - \\
11 articles/papers & $1(0.3 \%)$ \\
12 articles/papers & $1(0.3 \%)$ \\
13 articles/papers & $1(0.3 \%)$ \\
\hline TOTAL & $297(100 \%)$ \\
\hline
\end{tabular}

With three-quarters of the researchers publishing only one research article or paper in the five-year period to the end of 2003, and a further eleven per cent publishing only two research articles or papers, the field of school librarianship internationally has only a small core group of active researchers. Further, it is clear that some of the people who published one or two research articles or papers aimed at a school library audience or in some other way relevant to school librarianship during the period, do not actually regard themselves as researchers in the field of school librarianship or as contributors to the literature of school librarianship, even though their articles or papers may appear in our professional conference proceedings or our journals. They may be active researchers in another field (such as reading) who happened to undertake a project related in some way to school librarianship and were thus recorded in the database for the "Research and Researchers in School Librarianship" project. For example, one researcher who had presented research results at an international conference for school librarians, said, "I am not a librarian and don't research in the area of librarianship. I'm an English lit scholar with a 
specialism in children's literature”. Another said, “I'm not a researcher in school librarianship. My work is in multicultural librarianship and in this regard I have conducted some research that relates to the information needs of immigrant children and the role of school librarians. However, school librarianship does not permeate my research agenda.” Both declined to complete the questionnaire. On the other hand, many who had written or co-authored just one research article or paper published through the five-year period, do not seem to be active researchers in another field. People in this group may have undertaken a one-off action research project, or undertaken a project for a higher degree without doing any further research, or contributed as co-author to a paper by another researcher. Thus our field of school librarianship is not as replete with researchers as the total in Table 4 would perhaps suggest. On the other hand, it could be said to be a strength that our field is enriched through the work of so many researchers from other fields.

What are the characteristics of the people who write research articles and papers in the field of school librarianship?

Although completed questionnaires were still arriving when this paper was being written, it did prove possible to begin the analyses of the responses of the 43 current active researchers, that is, those who had published at least three research articles or papers in English related to school librarianship in the period 1999 to 2003 inclusive. Of this group, 31 (72.1\%) replied in time to have their responses included in the data set for analysis for the conference paper. Readers should bear in mind that analysis of this data is continuing and while this response rate could be considered very good, nevertheless the total "population" of the study (active researchers in the field of school librarianship) is very small and it may even be that another reminder will be sent to non-respondents to encourage a greater response rate.

Table 5: The Active Researchers, By Zone of Residence $n=31$

\begin{tabular}{l|l}
\hline IASL Membership Zones for Countries & Number (\%) of Researchers \\
\hline Zone A (the wealthiest countries) & $28(90.3 \%)$ \\
Zone B & $1(3.2 \%)$ \\
Zone C (the least wealthy countries) & $1(3.2 \%)$ \\
Unknown & $1(3.2 \%)$ \\
\hline TOTAL & $31(100 \%)$ \\
\hline
\end{tabular}

Table 6: The Main Job Held by the Active Researchers $n=31$

\begin{tabular}{l|l}
\hline Job Description (Main Job) & Number (\%) of Active Researchers \\
\hline Teacher Librarian / School Librarian / School Library & $4(12.9 \%)$ \\
Media Specialist & \\
University/college Professor (or equivalent) & $5(16.1 \%)$ \\
University/college Associate Professor (or equivalent) & $8(25.8 \%)$ \\
University/college Assistant Professor (or equivalent) & $8(25.8 \%)$ \\
Researcher in a library system/authority & $1(3.2 \%)$ \\
University Researcher & $2(6.4 \%)$ \\
Privately employed consultant or researcher & $1(3.2 \%)$ \\
Other & $2(6.4 \%)$ \\
\hline TOTAL & $31(100 \%)$ \\
\hline
\end{tabular}


It is already clear, though, that in relation to the characteristics of the active researchers, the data from the survey generally support the findings of the study of the authors who contributed research articles to School Libraries Worldwide (Clyde \& Oberg, 2004) cited above. Most were working in the developed countries. However, when the total number of active researchers is so small, listing the respondents by country of residence would mean the possibility that some researchers could be identified relatively easily. For this reason, an alternative way of presenting the data relating to country of residence was sought. For membership purposes, IASL divides the countries of the world into three zones based on the published gross national product indexes (see http://www.iasl-slo.org/joiniasl.html). The great majority of the active researchers (90\%) were working in countries in Zone A (comprising the wealthiest countries) with less than four per cent of the active researchers working in Zone B and less than four per cent in Zone C. Just four countries, the United States of America, Canada, Australia, and the United Kingdom, together accounted for almost three-quarters $(74.2 \%)$ of the active researchers, with 29 per cent coming from the United States alone.

The great majority of the active researchers were university or college faculty members. People holding the positions of full Professor, Associate Professor, Assistant Professor, and their equivalents in different countries, together accounted for 68 per cent of the active researchers who responded. Only four active researchers (12.9\%) were working in schools as a school librarian, teacher librarian, school library media specialist, or equivalent. The finding of the analysis of research articles in School Libraries World (Clyde \& Oberg, 2004), that even when research is based in schools, it is more likely to be reported by a university or college faculty member (as author or co-author), was confirmed by the results of this analysis of characteristics of the active researchers. Furthermore, the university/college faculty members were expected to do research as part of their job, as were people occupying researcher positions (Table 7), whereas this was not the case for the school library practitioner.

Table 7: Active Researchers Expected to do Research as Part of their Job $n=31$

\begin{tabular}{l|l}
\hline Response & Number (\%) of Active Researchers \\
\hline Yes & $24(77.4 \%)$ \\
No & $7(22.6 \%)$ \\
Unsure & - \\
\hline TOTAL & $31(100 \%)$ \\
\hline
\end{tabular}

What issues are of concern to the researchers and what do they perceive to be barriers to doing research?

Respondents generally were convinced of the value of research and the importance of undertaking research projects. This is reflected in the reasons given for doing research in the field of school librarianship. For one respondent, for example, the critical factor was the "belief that the 'profession' must be built on a strong foundation of research, which informs practice and provides direction for ongoing development of the profession." For another, it was an "interest in best practice and evidence-based approaches as a practitioner" that led to involvement in research. 
Others were motivated by the belief that there was "not enough research being done in [the school library media field]”.

This idea that there is "not enough research" in our field was evident in the responses in a number of ways, not least of which was a perception of the need for school librarians to make a contribution to the research. "We desperately need more research in this field. I wish more practitioners would get involved in reading and conducting research.” However, comments like this were sometimes tempered by an appreciation of the constraints on practitioners: "Time is against TL practitioners in schools working on their own research project so they need to be integrated into daily workplace like action research projects." Nevertheless, even if they did not do research themselves, school librarians could help to create a more positive research climate for our profession; for example, "Practitioners need to build a culture of research awareness. If research is unknown or ignored, what's the point?". One researcher lamented, "Practitioners do not generally read research. What are the implications of this for producers and writers of research? Blocks the iterative process of research $\rightarrow$ practice $\rightarrow$ reflection $\rightarrow$ research.”

School library practitioners were not the only people singled out for blame; administrators ("Administrators do not value research so therefore do not initiate or support it") and educational decision-makers ("Political powers are disregarding the results of research ... right now - highly frustrating".) were also cited. Some respondents felt that the researchers themselves were partly to blame: "Researchers (myself included) have a tendency to publish in school/library related journals. We should send more articles to education/ICT journals and submit more papers to education/ICT conferences." For others, the quality of the research in our field was a problem; one respondent was "concerned about the tendency of US school library community adoption of a national study with a questioned methodology as proof that school libraries are essential. This is a huge area where we need research of the highest quality.”

Others drew attention to developments in the wider educational setting that were influencing research in school librarianship. In one country, "School library jobs have disappeared in the past 8 years. School libraries are either staffed by full-time teachers or by 'extra' staff paid for by parents' fees." This situation does not help to encourage research. In another country, it was difficult to encourage people to undertake research in the field of school librarianship when "only about $10 \%$ of schools have libraries". For this respondent, the "burning issue ... is how the 'progressive' curriculum is being implemented in the absence of school libraries"; how children can still acquire the skills needed for lifelong learning when they do not have access to a library in the school.

While most of the active researchers were faculty members in universities or colleges (often in library schools), the library schools themselves were a source of concern, for a number of reasons. First, it was perceived that within many library schools, the emphasis in the research program is primarily on academic libraries, special/government libraries, then public libraries, and then at the bottom of the heap, library services to children and school libraries. "Many [library schools] do not value [school librarianship] research or programs that specialise in this field. They often do not target specialists in [school librarianship]. It is common for [library schools] to 
have one or two ... in [school librarianship] only and the courses may be taught by school librarians or people who do not understand the issue. In this climate [research] in [school librarianship] will be a low low low priority." Secondly, as the above response also suggests, research in school librarianship "is suffering because many US universities hire adjuncts to teach in the area of school librarianship. These people have no incentive or requirement to do research. It is difficult to recruit full-time school media faculty because most teacher-librarians make higher salaries in the school systems." Thirdly, the way in which duties were allocated in library schools often compounded the problem: "Many university faculty who oversee school library media programs have heavy and complex advising duties. Often these are not considered by library schools when they set up research expectations. We either need more school media faculty (difficult to find) or adjustments on expectations.”

Table 8: Perceived Barriers to Doing Research in School Librarianship:

Responses from the Active Researchers $n=29$

\begin{tabular}{|c|c|}
\hline Perceived Barrier & Number of Active Researchers \\
\hline Lack of time for research & 20 \\
\hline Lack of funds for research & 18 \\
\hline $\begin{array}{l}\text { A perception that the major funding agencies have little } \\
\text { interest in funding projects in the field of school } \\
\text { librarianship }\end{array}$ & 10 \\
\hline Limited dissemination of existing research findings & 6 \\
\hline Lack of support for research & 5 \\
\hline $\begin{array}{l}\text { A poor "research environment" in the field of school } \\
\text { librarianship }\end{array}$ & 5 \\
\hline $\begin{array}{l}\text { Lack of recognition/understanding of the value of } \\
\text { research on the part of the school library practitioner }\end{array}$ & 5 \\
\hline $\begin{array}{l}\text { Recent funding cuts in library services or school library } \\
\text { services locally }\end{array}$ & 5 \\
\hline Lack of grant writing or proposal writing skills & 3 \\
\hline $\begin{array}{l}\text { Lack of recognition/understanding of the value of } \\
\text { research on the part of educational or library } \\
\text { administrators }\end{array}$ & 3 \\
\hline $\begin{array}{l}\text { Lack of research background among practitioners, } \\
\text { administrators }\end{array}$ & 3 \\
\hline $\begin{array}{l}\text { Lack of places to publish the results of research in } \\
\text { school librarianship }\end{array}$ & 2 \\
\hline Recent staffing cuts locally & 1 \\
\hline $\begin{array}{l}\text { Lack of writing skills that prevents people from writing } \\
\text { research reports and articles }\end{array}$ & 1 \\
\hline Lack of research skills/expertise & 1 \\
\hline Fear of the peer review / refereeing process & \\
\hline Other & 5 \\
\hline
\end{tabular}

On the survey questionnaire, one question specifically asked "what, for you, are the main barriers to doing research in the field of school librarianship?" Respondents were requested to mark up to three items on a list of "barriers to doing research" that had been compiled as a result of a review of the literature. The results are presented in Table 8. Perhaps not surprisingly given the comments above, the main barriers were lack of time for research (even for those who were expected to undertake research as part of their jobs), lack of funds for research, a perception that 
the major funding agencies were not interested in funding research projects in the field of school librarianship, and local funding and staffing problems. Only one significant "barrier" was added to the research-based list by the respondents: the difficulties involved in gaining access to schools in order to do school-based research, described by one respondent as "red tape issues". Respondents recognized that schools had to be careful about who had access to the children, but nevertheless found the procedures time-consuming and ultimately negative in their impact on schoolbased research.

Are there any differences between the more active and the less active researchers?

At the time this paper was being written, responses were still arriving, and only some of the data from the active researchers had been analysed. Preliminary trawls of the available data do suggest that there are some differences between the most active researchers in the field of school librarianship and those who have published fewer research articles and papers in the field of school librarianship, though the differences do not necessarily manifest themselves in the ways one might expect. The conference presentation itself will provide more discussion of this question, based on analyses of the data to be carried out over the coming months.

\section{Conclusions}

Perhaps the most salutary finding of this study is that there are so few active researchers in the field of school librarianship at the international level. While the numbers grew between 1996-2000 and 1999-2003, the proportion of active researchers to less active researchers did not change. Further, the measure of an "active researcher in school librarianship" that was used in this study (someone who publishes at least three research articles or papers in the field of school librarianship over a five-year period) was very generous. Most universities, including my own, would find this level of research performance from a faculty member unsatisfactory. However, it has to be said that some of the researchers were active in more than one research field (for example, school librarianship and education for library and information science, or school librarianship and use of the Internet) and in these cases it becomes extremely difficult to actually measure the research productivity of individual researchers without access to their personal curriculum vitae unless the information is made public through an institution's annual report or other publication. If a more stringent measure of research productivity in school librarianship were to be used, such as one research article or paper per year, then we would have no more than 16 active researchers published in English in the field of school librarianship from 1999 to 2003 inclusive.

However, while this group represents the core of researchers in our field, nevertheless a great deal of work is published each year by people who make only one or two contributions to our research literature in English. Some of these people are researchers from other fields who become involved for a time in a project that touches on the concerns of school librarians. The others are mostly people who undertake one project, perhaps for a higher degree, and then disappear from the research scene of our profession. If some of the barriers to doing research could be reduced, if we could create a better research climate for the profession, then these people might be encouraged to continue to tackle research projects and to publish the results. 
Assuming that, like many of the respondents, we believe that research in school librarianship is important, then a major challenge for the profession becomes the elimination of as many of the barriers to research as possible. This is not something that can be left to the researchers. School librarians, teachers, principals, educational administrators, and library schools, all have a role in creating a positive research climate for our profession; so do the professional associations, including the International Association of School Librarianship. Researchers themselves can assist this process by publishing their research results in journals and conference proceedings that are read by teachers and educational decision-makers as well as in journals for school librarians.

It remains a concern that the group of core researchers is so unrepresentative of school librarianship worldwide. By and large, the active researchers work in developed countries (overwhelmingly in just four developed countries), and they hold positions as faculty members in universities or colleges. As Dianne Oberg and I (Clyde \& Oberg, 2004, 13-14) said of the results of our study of research contributors to School Libraries Worldwide, the publications "draw heavily on the research and practice of first world English-speaking nations where school libraries are particularly well-developed. School librarians from other areas of the world will find fewer articles that resonate with their contexts and their challenges." In addition, it is probable that the barriers to doing research that were described above, and which came predominantly from the experiences of first-world respondents, operate to an even greater degree in developing countries.

Research has the potential to support information leadership in a culture of change, to refer back to the beginning of this paper. However, if research is to be worth using, leaders and decision-makers also have a responsibility to help create a research climate within the educational setting, so that quality research is encouraged and facilitated.

This study of "Researchers in School Librarianship" is far from completed, as has been indicated several times already. Data analysis of the questionnaire responses will continue through 2005. As well as looking at the characteristics of the active and less active researchers, the analyses will also address a number of other issues, including the way in which the quality of research publications is assessed in the field of school librarianship, the ways in which the research productivity of the researchers is measured, the journals in which the researchers prefer to publish their research articles, and the influence of the library schools on the research output in the field of school librarianship.

\section{References}

Blake, V.L.P. (1994). Faculty productivity, journal prestige, and school library media faculty. School Library Media Quarterly, 22(3): Spring, 153-158.

Cano, V., \& Rey, C. (1993). Ten years of Spanish library and information science research: A bibliometric study. Paper presented at the $59^{\text {th }}$ IFLA Conference, Barcelona, Spain, August 1993. [197THEOR-E]. 
Clyde, L.A. (Ed.) (1996). Sustaining the Vision: A Collection of Articles and Papers on Research in School Librarianship. Castle Rock, CO: Hi Willow for the International Association of School Librarianship.

Clyde, L.A. (2001). Behind the inspiring connections: Research and researchers in school librarianship. A progress report. In Hughes, P. and Selby, L. (Eds). Inspiring Connections: Learning, Libraries and Literacy, Proceedings of the Fifth International Forum on Research in School Librarianship... Auckland, New Zealand, 9-12 July 2001 (pp.65-77). Seattle, WA: International Association of School Librarianship.

Clyde, L.A. (2002). Developing the knowledge base of the profession: Research in school librarianship. In Singh, D., Abdullah, A., Foneska S., and de Rozario, B. (Eds). School Libraries for a Knowledge Society: Proceedings of the $31^{\text {st }}$ Annual Conference of the International Association of School Librarianship... Petaling Jaya, Malaysia, 5-9 August 2002 (pp.55-75). Seattle, WA: International Association of School Librarianship.

Clyde, L.A., \& Oberg, D. (2004). LIS journals as a source of evidence for evidence-based practice: The case of School Libraries Worldwide. Paper for the Open Session of the Section for Library and Information Science Journals, Annual Conference of the International Federation of Library Associations and Institutions, August 2004. Available from http://www.ifla.org/IV/ifla70/papers/051eClyde_Oberg.pdf (accessed 10 April 2005).

Grover, R., \& Fowler, S.G. (1993). Recent trends in school library media research. School Library Media Quarterly, 21(4): Summer, 241-247.

Henri, J., \& Freeman, A. (1998). Australian research in the field of teacher librarianship: An exploratory study. Access, 12(2): May, 28-31.

Järvelin, K., \& Vakkari, P. (1990). Content analysis of research articles in library and information science. Library and Information Science Research, 12(4): 395-421.

Järvelin, K., \& Vakkari, P. (1993). The evolution of library and information science 1965-1985: A content analysis of journal articles. Information Processing and Management, 29(1): 129-144.

Koufogiannakis, D., \& Slater, L. (2004). A content analysis of librarianship research. Journal of Information Science, 30(3): 227-

Palsdóttir, G., Arnadóttir, I., Sverrisdóttir, I., Blöndal, R., \& Clyde, L.A. (1997). Published research about library and information science in or related to Iceland. Nordic Yearbook of Library, Information and Documentation Research. Oslo: Novus forlag, 85-108.

Rochester, M. (1995). Library and information science research in Australia 1985-1994: A content analysis of research articles in The Australian Library Journal and Australian Academic and Research Libraries. Australian Academic and Research Libraries, 26: September, 163-170.

Stroud, J.C. (1982). Research methodology used in school library dissertations. School Library Media Quarterly, 10(2): Winter, 124-134. 


\section{Author Note}

Dr L. Anne Clyde is Professor in the Library and Information Science Department at the University of Iceland. An Australian citizen, she has worked in schools and universities in a number of countries, including Canada and Namibia, as well as in Australia and Iceland. Her teaching and research interests are related to the use of online information services and the Internet, and she has published several books in this field, including Managing InfoTech in School Library Media Centers (1999) and Weblogs and Libraries (2004). She also undertakes research about research through her ongoing "Research and Researchers in School Librarianship" project. She is Webmaster for the International Association of School Librarianship. 
Reproduced with permission of the copyright owner. Further reproduction prohibited without permission. 